5. Гершунский Б.С. Философия образования для XXI века : в поисках практикоориентированных образовательных концепций. Москва : Изд-во "Совершенство", 1998. 608 с.

6. Кремень В.Г. Філософія людиноцентризму в освітньому просторі. 2-е вид. Київ : Т-во: Знання України, 2010.520 c.

7. Лисенко Н.В. Тенденції розвитку дошкільної освіти у сучасних європейських країнах: перспективи для творчих запозичень. Освітній простір Украйни : науковий журнал. ІваноФранківськ, 2015. Вип: 5 і 6.

8. Лисенко О.М. Майбутній педагог українського дошкілля у просторі професійно-ціннісних орієнтацій. Монографія. Івано-Франківськ, 2018. 407 с.

\title{
References
}

1. Bekh I.D. Humanizatsiia vykhovnoho protsesu. Entsyklopediia dlia fakhivtsia sotsialnoi sfery. 2-e vydannia / za zah.red.prof. D. Zvierievoi. Kyiv - Simferopol : Universum, 2013. S. 33-34.

2. Bielienka H.V. Vykhovatel ditei doshkilnoho viku: stanovlennia fakhivtsia $v$ umovakh navchannia. Kyiv : Svitych, 2006. $304 \mathrm{~s}$.

3. Bohush A.M. Kompetentnisnyi pidkhid u protsesi profesiinoi pidhotovky maibutnoho vykhovatelia doshkilnoho zakladu. Naukovi pratsi. Seriia : Pedahohika, psykholohiia i sotsiolohiia. Donetsk : DVNZ “Don NTU”. 2009. Vyp.5(155), ch.I. S. 194-200.

4. Havrysh N.V. Oriientatsiia na rozvytok subiektnosti studenta u protsesi pidhotovky profesiino kompetentnykh fakhivtsiv z doshkilnoi osvity/ N.V.Havrysh// Zb. nauk. prats Berdian. derzh. ped. un-tu. Seriia : Pedahohichni nauky. Berdiansk: BDPU, 2007. S.44-49.

5. Hershunskyi B.S. Fylosofyia obrazovanyia dlia XXI veka : v poyskakh praktyko-oryentyrovannykh obrazovatelnykh kontseptsyi. Moskva : Yzd-vo "Sovershenstvo", 1998. $608 \mathrm{~s}$.

6. Kremen V.H. Filosofiia liudynotsentryzmu v osvitnomu prostori. 2-e vyd. Kyiv : T-vo: Znannia Ukrainy, 2010. $520 \mathrm{~s}$.

7. Lysenko N.V. Tendentsii rozvytku doshkilnoi osvity u suchasnykh yevropeiskykh krainakh: perspektyvy dlia tvorchykh zapozychen. Osvitnii prostir Ukrainy : naukovyi zhurnal. IvanoFrankivsk, 2015. Vyp: 5 i 6.

8. Lysenko O.M. Maibutnii pedahoh ukrainskoho doshkillia u prostori profesiino-tsinnisnykh oriientatsii. Monohrafiia. Ivano-Frankivsk, 2018. $407 \mathrm{~s}$.

Одержано статтю: 22.10 .2019

Прийнято до друку: 6.11 .2019

УДК $37.015 .31: 17.022 .1$

DOI:10.15330/esu.17.252-258

\author{
Мар'яна Марусинецьь, \\ доктор педагогічних наук, професор, \\ Національний педагогічний університет \\ ім. М.П. Драгоманова (м. Київ, Україна) \\ Mariana Marusynets, \\ Doctor of pedagogical sciences, Professor, \\ National Pedagogical Dragomanov University \\ (Kiev, Ukraine) \\ marusynetsm(aukr.net
}

\section{ПІДГОТОВКА МАЙБУТНІХ УЧИТЕЛІВ ДО РЕАЛІЗАЦЇ̈ ЗАВДАНЬ МОРАЛЬНОГО ВИХОВАННЯ УЧНІВСЬКОЇ МОЛОДІ}

\section{PREPARATION OF FUTURE TEACHERS FOR REALIZATION THE TASKS OF MORAL EDUCATION OF PUPILS' YOUTH}

У статті порушено питання про проблеми виховання сучасної учнівської молоді, вказано на ризики, зумовлені сочіальними й освітніми змінами, які відбуваються в суспільстві. Обов'язковою професійною якістю майбутнього вчителя повинно стати сформований моральний світогляд, заснований на гуманістичних загальнолюдських цінностях та етико-філософських законах суспільства, його традичіях, національній свідомості. Основними засобами визначено створення навчального середовища проведення лекційних та семінарських занять з елементами інноваційних технологій під 
час вивчения дисциплін спечіального та професійного чиклів у проџесі фахової підготовки у педагогічних вишах.

Ключові слова: моральне виховання, етичне виховання, павчальне середовище, учні стариої иколи, майбутній вчитель, підготовка фахівців у педагогічних вишах.

The article addresses the problems of upbringing of the modern student youth, points out the risks caused by social and educational changes that are taking place in the society. Their solution depends on the willingness of the modern teacher to carry out this process in a school environment. To do this, a graduate of a pedagogical college must have not only knowledge of techniques, but also educational technologies that will promote the development of moral and ethical behaviors in students; purposefully influence the formation of their consciousness, but also the ability to act on the moral standards defined by society at the micro - macro - meso levels. However, modern teachers are incomplete in their readiness for this type of work because of a series of contradictions caused by the educational needs for which they are intended and the challenges of the times. The school, today's student, is waiting for a teacher who must be a free, spiritual person, capable of independent moral decisions and actions; have strong moral principles and beliefs; competent in matters of morality and moral values, to profess them; acts and actions to form standards of morality and etiquette. The moral professional outlook, based on humanistic values and ethical and philosophical laws of society, its traditions, and national consciousness, should become a mandatory professional quality of the future teacher. The main means are the creation of a learning environment - conducting lectures and seminars with elements of innovative technologies in the study of disciplines of special and professional cycles in the process of professional training in pedagogical universities.

Key words: moral education, ethical education, educational environment, high school students, future teacher, training specialists in pedagogical universities.

\section{Постановка проблеми у загальному вигляді та зв'язок із важливими науковими чи практичними завданнями. \\ XXI століття характеризується докорінними змінами не тільки в усіх} суспільно-політичних, економічних структурах, а й духовно-моральних, серед яких переоцінка життєвих смислів та цінностей, нівелювання моральних принципів зумовлюють деформацію особистісних і суспільних змін, породжують соціальну розгубленість, психологічну фрустрацію, i людина заповнює вакуум тими цінностями, які далеко не ідентифікуються 3 ïi моральними установками та життєвими нормами. На думку вчених - це лише тимчасовий ефект, однак, він тяжіє до суттєвих ризиків. Вони полягають у тому, що внаслідок таких змін, учнівська молодь піддається найрізноманітнішому впливу (грубість, безтактність, байдужість, недисциплінованість, бродяжництво, крадіжки, хуліганство й ін.), що $\epsilon$ серйозною проблемою для всього людства. Свідченням цього є дані, отримані за результатами опитування директорів шкіл та вчителів, які констатують, що кількість дітей групи ризику за останні роки різко зросла і становить більше половини [4]. Цей факт зумовлений тим, що в учнівської молоді та дітей недостатньо сформовані моральні настанови та переконання, воля, характер, уявлення про сенс життя, загальна культура.

Вирішальним для вирішення цієї проблеми є сім'я (первинний осередок) та школа - готовність учителів сучасної загальноосвітньої школи до здійснення виховного процесу. У цьому сенсі велику роль відіграють вищі навчальні заклади, які здійснюють підготовку вчителів до формування в учнів морально-етичних цінностей в умовах соціуму. 
Аналіз останніх досліджень і публікацій, в яких розглядалися аспекти цієї проблеми i на яких обгрунтовусться автор; виділення невирішених раніше частин загальної проблеми.

Підготовка вчителів до основ духовно-моральних цінностей представлені в роботах І. Беха, М. Боришевського, А. Бородіної, Л.Гладких, Л. Короткової, В.Перевертайло, Е. Помиткіна, О. Савченко, Л. Шевченко, Н. Шітякова, О. Янушкявічене та ін. Вчені наголошують на тому, що завдання підготовки педагогів до викладання основ морального та етичного виховання повинно мати комплексний характер i враховувати відповідне середовище, у якому здійснюватиметься етапна послідовність їхньої професійної підготовки.

Для реалізації цього завдання вчитель сам повинен мати високий рівень духовно-моральної культури, у зв'язку з чим виникають певні складнощі та суперечності у їх підготовці в сучасних вишах, а саме: між ретельним розробленням абстрактної мети виховання і реально діючою теорією морального виховання та практикою; об'єктивно існуючими можливостями вибору гуманістичних цінностей $i$ невмінням використовувати їх в ролі педагогічних орієнтирів; збільшенням кількості нестандартних, конфліктних шкільних ситуацій та актуальними здібностями вчителів/педагогів щодо їх вирішення та корекції. Ці та низка інших суперечностей вказують на необхідність оновлення змісту підготовки майбутніх учителів до виховання у школярів моральних та етичних норм поведінки.

Виклад основного матеріалу дослідження 3 повним обгрунтуванням отриманих наукових результатів.

Проблема морального виховання завжди була в центрі уваги вітчизняної педагогіки. Про це свідчать праці видатних педагогів, філософів, які вважали моральне виховання головною проблемою. Видатні філософи минулого, зокрема Т. Гоббс, вважали, що добропорядна поведінка залежить від конкретних соціально-політичних обставин, матеріального становища громадян, а Р. Декарт був переконаний у тому, що моральну регуляцію поведінки людини здійснює совість. За Дж. Локком, моральне виховання залежить від звичаїв, що формують совість, яка $є$ думкою або судженням людини про моральну правильність чи недоречність певної поведінки, а Ф. Вольтер надавав пріоритети таким якостям, як доброзичливість до інших осіб, любові до себе та інших. На думку Д. Дідро, спроможність людини відрізняти чесноту від вади (пороку), відчувати любов до першої та огиду до другої є природженими, а вплив конкретного зовнішнього середовища, почуття щастя та розуму є визначальними у виборі людиною того чи іншого виду поведінки. Тобто вони ратували за моральне оздоровлення суспільства, за виховне середовище, в якому відбувається процес становлення особистості дитини.

Проблема морального виховання активно розробляється і зарубіжними вченими, такими як: О.Ф. Больнов, Дж.Вільсон, Дж.Дьюи, Л.Кольберг, Р.Пітерс, Р.Рудольф, М.Уорнок, А.Харріс, К.Херст, Х.Штольц. У сучасних умовах деякі дослідники (Ю. Антонян, В. Емінов, В. Кудрявцев та ін.) висловлюють переконливі докази того, що у сім'ях, де поважають і шанують один одного, актуалізується виховання у дітей таких якостей, як колективізм, доброзичливість, уважність, здатність до співпереживання, самостійність, ініціативність, вміння вирішувати конфліктні ситуації, знаходити вихід із екстремальних ситуацій тощо. Такі базові якості, зазначає О. Савченко, О. Тарнавська, Г. Ткаченко, необхідно прищеплювати з дитинства, починаючи з сім'ї та навчального середовища (дитячого садка, школи). 
У контексті дослідження на особливу увагу заслуговує питання професійної підготовки майбутніх учителів до морального виховання дітей та молоді. Для реалізації іiі звернемось до наукових досліджень учених, які вивчають цю проблематику (Е. Ашхаруа, М.І.Гей, А.А.Горбонідзе, А.К.Данилевич, А.А.Калюжний, М.П.Целих, Р.М.Хмурич).

3 аналізу їх учень, вкажемо на те, що нині підготовка майбутнього вчителя за означеним спрямуванням здійснюється в рамках традиційної парадигми - знаннєвої. Проблема наявної системи підготовки майбутніх вчителів до морального виховання криється у змісті виховного процесу, у якому присутня "якась усереднена і спрощена мораль”. Справжній процес виховання в суспільстві відбувається в зіткненнях, протидіï різних моральних позицій. Українська спільнота потребує такого вчителя, якому притаманні активність, динамічність, уміння швидко орієнтуватися в складних ситуаціях, робити моральний вибір, самостійно приймати моральні рішення, бути відповідальним за життя і виховання дітей, виконування своїх професійних функції. За О. Савченко, це - уміння вчитися, громадянська, інформаційна, комунікаційна, підприємницька, здоров'язбережувальна компетенції, ознаками яких є: відкритість, цілісність, гнучкість, неперервність, емоційність, варіативність, інтегрованість, комфортність, суб'єктність навчальної взаємодії. [5].

Щоб сформувати фахівця нового типу, необхідно привести систему його підготовки у відповідність з актуальними потребами тієї сфери, для якої він призначений і в якій покликаний працювати. Зміст та технології підготовки майбутнього вчителя повинні визначатися на основі педагогічного аналізу актуальних потреб суспільства, освітніх проблем педагогічних вишів та змін, які відбуваються в соціумі. Їх реалізація зумовлена тим, що школа і сучасний учень чекає вчителя, який повинен бути вільною, духовною особистістю, здатною на самостійні моральні рішення і вчинки; мати тверді моральні принципи й переконання; компетентним у питаннях моралі і моральних цінностях, сповідувати їх; вчинками і діями формувати еталони моралі та етикету.

Гуманістично орієнтований учитель повинен володіти позитивним ставленням до учня, приймати його як цілісну особистість, поважати погляди і цінності; бути терпимим до чужої думки та проблеми. Обов'язковою професійною якістю майбутнього вчителя повинно стати сформований моральний світогляд, заснований на гуманістичних загальнолюдських цінностях та етико-філософських законах суспільства, його традиціях, національній свідомості. Вона має таку ієрархічну значущість:

1. Висока моральність (любов до ближнього як комплекс якостей).

2. Емпатія (здатність співпереживання).

3. Педагогічна увагу і спостережливість (уміння бачити, чути дітей).

4. Мотивація (ціннісна орієнтація, розуміння дитячого світу, інтуїція)

5. Здатність до співпраці з дітьми (педагогічний такт).

6. Рефлексія (Самопізнання).

7. Вольова спрямованість (самокорекція) $[1 ; 3]$.

О. Матвієнко, О. Савченко та ін. визначають готовність вчителя до моральноетичного виховання як інтегративну характеристику особистості, що включає професійну компетентність щодо забезпечення його здатності до формування $\mathbf{y}$ молоді знань про систему моральних і духовних цінностей, створення умов для пошуку і знаходження ними особистісних смислів у взаємозв'язку з вихованням моральних почуттів і моральної поведінки [2;5]. 
Реалізація їх можлива за умови створення спеціального навчального супроводу для студентів - майбутніх учителів на заняттях $з$ фахових та психологопедагогічного циклів. Основними завданнями навчального супроводу є:

- знання студентів про вікові та психологічні особливості розвитку їх когнітивної, конативної, афективної сфер, на яких грунтуються уявлення учнів про мораль, моральні цінності та етикет;

- робота 3 учнівським самоврядуванням у школі 3 вирішення завдань моральноетичної освіченості сучасної молоді.

Що ж до підготовки майбутнього вчителя до виховної діяльності в загаль ноосвітній школі, то вона повинна грунтуватися на новій філософії. Виховний вплив на особистість за схемою “вимога - сприймання - дія" в умовах шкільного середовища нині не спрацьовує, оскільки не розкриває особливостей морального розвитку особистості, не враховує творчого освоєння нею моральних цінностей, позитивної мотивації вчинків.

Сама дефініція "виховання" потребує нового смислового завантаження та переосмислення: від зовнішнього "примусу" до внутрішнього - самопримусу, саморегуляції на основі віри й почуття обов'язку. 3 огляду на це підготовку майбутніх учителів доцільно розглядати як таких, котрі не тільки навчають, а й здійснюють корекцію виховних впливів. Як зауважує I. Бех, від вимоги “Ти мусиш" до “Я хочу". І щоб це не відбулося, потрібно виробити у себе інноваційний стиль діяльності, визначити пріоритети, механізми їх практичної реалізації [1].

3 метою підготовки вчителів до вирішення цих завдань доцільним $\epsilon$ розширення навчального матеріалу на лекційних та семінарських заняттях 3 предметів психологічного й педагогічного циклів на всіх освітніх рівнях, зокрема на OC "бакалавр" під час вивчення навчальних дисциплін: етика та естетика, історія педагогіки, теорія та методика виховання, педагогіка, загальна психологія, методика навчання освітньої галузі "Громадянської та історичної" психологія вікова та педагогічна, дитяча література, дидактика, технологія навчання; на ОС “магістр": освітня політика, педагогіка вищої школи, психологія вищої школи.

Дискусійними темами для студентів 3 формування моральних компетенцій обрано: “Актуальність духовно-морального розвитку школярів і сучасні проблеми", “Моральний портрет сучасного учня", “Люди без моралі, які вони?”, “Що робити якщо ... ?”, “Як діяти в ситуації, якщо поруч ....”, “Що я знаю про етикет”, “Чи прагну бути чесною і культурною людиною?”, “У чому полягає сенс життя у ситуації вибору", "Людина - це мета, чи засіб існування?" й ін.

Для формування етичних норм, обрано дискусії: "Золоте слово народної мудрості”, “Шукай себе, поки не зустрінеш”, “Живу я в світі тільки раз”, “Чарівне слово ..." й ін. Це дає можливість майбутньому фахівцю оволодіти новими знаннями про сутність, особливості духовно-моральної освіченості, відмінності й спільності духовної і моральної культури; формування професійних компетенцій (ціннісносмислових, загальнокультурних, інформаційних, комунікативних, компетенції особистісного вдосконалення); формування мотиваційно-ціннісного відношення вчителів до вирішення завдань моральної освіченості (розуміння потреби суспільства в їх всебічному рішенні; відповідальності за духовну і моральну вихованість учнів; психолого-педагогічна підтримка дітей в їх прагненні до духовноморального вдосконалення та самореалізаціі). Розширити професійні компетенції про: понятійно-термінологічну базу духовно-моральної освіти (етика, мораль, моральність, етична культура, моральна культура, загальнолюдські цінності, спосіб 
життя, духовність); історико-педагогічний досвід моральної та етичної освіченості; цілі, завдання, зміст й особливості моральної та етичної освіти учнів старшої школи; зміст морального та етичного компонентів, їх потенціал та шляхи реалізації; визначати ступінь значущості для учнів моральної та етичної культури та норм поведінки; розробляти спільно з батьками навчальні проекти, спрямовані на формування моралі та етичних настанов у школярів; використовувати методи педагогічного супроводу сім'ї з питань моральної й етичної освіченості; проводити діагностику готовності учнів до моральних та етичних поведінкових дій, аналізувати ii результати та здійснювати корекційну й профілактичну роботу; володіти сучасними інноваційними технологіями і засобами організації освітнього процесу, спрямованого на створення сприятливого середовища для школярів в учнівському та родинному колі; формувати вміння і звички моральної поведінки школярів, які б стали потребою і реалізовувалися б у будь-якій ситуації та умовах; залучати до участі у різних заходах: волонтерські акції, волонтерський рух милосердя, дискусійні клуби спілкування, етичних міркувань, бесіди на природі, зустрічі (за інтересами учнів).

Формами контролю для студентів обрано: тестування, написання есе, анкетування, укладання портфоліо на тему "Моральна та етична культура учнівської молоді в умовах соціальних змін" дає змогу підвищити рівень професійної підготовки вчителів до моральної та етичної освіченості старших школярів.

Висновки дослідження і перспективи подальших розвідок цього напряму. Наведене вище $є$ підставою для висновку про те, що професійну підготовку майбутніх учителів розглядаємо як процес формування їхньої готовності до здійснення діяльності, спрямованої на навчання, виховання та розвиток учнівської молоді. Основними засобами визначено створення навчального середовища - проведення лекційних та семінарських занять 3 елементами інноваційних технологій під час вивчення дисциплін спеціального та професійного циклів у процесі фахової підготовки у педагогічних вишах.

Перспективу подальших досліджень вбачаємо в розробленні програми психолого-педагогічного супроводу для майбутніх учителів 3 виховання моральних та етичних норм поведінки в учнів старшої школи.

\section{Література}

1. Бех І. Д. Концептуальна модель Я-центрованості у вихованні та духовному розвитку особистості. Педагогіка і психологія. 2015. № 3 (88). С. 5-15.

2. Матвіснко О. В. Виховання молодших школярів: теорія і технологія. К.: ВД "Стилос", 2006. $-543 \mathrm{c}$.

3. Марусинець М.М. Професійна рефлексія майбутнього вчителя початкових класів: теорія і практика формування [монографія]У мань: ПП Жовтий О. О., 2012. - 419 с.

4. Мовчан В.С. Етика: [навч. мет. посіб]. К.: Знання, 2008. - 303 с.

5. Савченко О.Я.Виховний потенціал початкової освіти [Текст]: посібник для вчителів і методистів почат. навчання.2-ге вид., доповн., переробл. К: Богданова А.М. , 2009. - 226 с.

6. Ткаченко Г.М. Виховання школярів засобами слова у творчій спадщині В.О.Сухомлинського дис. канд. пед. наук : 13.00.01. Київ, 2000. - 203c.

\section{References}

1. Bekh I. D. Kontseptualna model Ya-tsentrovanosti u vykhovanni ta dukhovnomu rozvytku osobystosti. Pedahohika i psykholohiia. 2015. № 3 (88). S. 5-15.

2. Matviienko O. V. Vykhovannia molodshykh shkoliariv: teoriia i tekhnolohiia. K.: VD "Stylos", 2006. $-543 \mathrm{~s}$.

3. Marusynets M.M. Profesiina refleksiia maibutnoho vchytelia pochatkovykh klasiv: teoriia i praktyka formuvannia [monohrafiia]Uman: PP Zhovtyi O. O., 2012. - $419 \mathrm{~s}$.

4. Movchan V.S. Etyka: [navch. met. posib]. K.: Znannia, 2008. $-303 \mathrm{~s}$. 
5. Savchenko O. Ya. Vykhovnyi potentsial pochatkovoi osvity [Tekst] : posibnyk dlia vchyteliv i metodystiv pochat. navchannia. 2-he vyd., dopovn., pererobl. K. : Bohdanova A. M., 2009. - $226 \mathrm{~s}$.

6. Tkachenko H.M. Vykhovannia shkoliariv zasobamy slova $u$ tvorchii spadshchyni V.O.Sukhomlynskoho : dys. kand. ped. nauk : 13.00.01. Kyiv, 2000. $-203 \mathrm{~s}$.

Одержано статтю: 18.09.2019

Прийнято до друку: 16.10.2019

УДК $378.22: 373.2$

DOI: $10.15330 /$ esu. $17.258-264$

\author{
Маріанна Матішак, \\ кандидат педагогічних наук, доцент, \\ ДВНЗ “Прикарпатський національний \\ університет імені Василя Стефаника" \\ (м. Івано-Франківськ, Україна) \\ Marianna Matishak, \\ Candidate of pedagogical sciences (PhD), \\ Associate Professor, Vasyl Stefanyk Precarpathian \\ National university (Ivano-Frankivsk, Ukraine) \\ mariannamatishak@ukr.net
}

\author{
Ірина Скоморовська, \\ кандидат педагогічних наук, доцент, \\ ДВНЗ "Прикарпатський національний \\ університет імені Василя Стефаника" \\ (м. Івано-Франківськ, Україна) \\ Iryna Skomorovska, \\ Candidate of pedagogical sciences ( $\mathrm{PhD})$, \\ Associate Professor, Vasyl Stefanyk Precarpathian \\ National university (Ivano-Frankivsk, Ukraine) \\ iskomor@ukr.net \\ Ірина Дідух, \\ кандидат педагогічних наук, доцент, \\ ДВНЗ "Прикарпатський національний \\ університет імені Василя Стефаника" \\ (м. Івано-Франківськ, Україна) \\ Iryna Didukh, \\ Candidate of pedagogical sciences $(\mathrm{PhD})$, \\ Associate Professor, Vasyl Stefanyk Precarpathian \\ National university (Ivano-Frankivsk, Ukraine) \\ mail@pnu.edu.ua
}

\section{ФОРМУВАННЯ ДЕМОКРАТИЧНОЇ КУЛЬТУРИ МАЙБУТНІХ МАГІСТРІВ ДОШКІЛЬНОЇ ОСВІТИ: ОСОБИСТІСНО ОРІЕНТОВАНИЙ ПІДХІД}

\section{FORMING OF DEMOCRATIC CULTURE OF FUTURE MASTERS OF PRESCHOOL EDUCATION: A PERSONALLY ORIENTED APPROACH}

У статті проаналізовано теоретико-методологічні аспекти формування демократичної культури майбутніх магістрів доикільної освіти в освітньому прочесі 3 ВО. Доведено, ио зміст та організачія професійної педагогічної підготовки в умовах магістратури мас передбачати формування готовності майбутніх фахівців освітньої сфери до здійснення професійної діяльності на засадах демократичних чінностей та гуманістичних вимірів. У статті виокремлено основні положення реалізачії особистісно орієнтованого підходу під час формування демократичної культури студентів в умовах магістратури, а саме: ціннісно-змістове наповнення навчальних дисциплін; формування професійно значуцих якостей демократичної особистості; використання активних форм $і$ 